\title{
Two Genetically Diverse Groups of Strains Are Included in Xanthomonas campestris pv. vesicatoria $\dagger$
}

\author{
R. E. STALL,${ }^{1 *}$ C. BEAULIEU, ${ }^{1}$ D. EGEL,${ }^{1}$ N. C. HODGE,${ }^{1}$ R. P. LEITE ${ }^{1}$ G. V. MINSAVAGE, ${ }^{1}$ \\ H. BOUZAR, ${ }^{2}$ J. B. JONES, ${ }^{2}$ A. M. ALVAREZ, ${ }^{3}$ AND A. A. BENEDICT ${ }^{3}$ \\ Department of Plant Pathology, University of Florida, Gainesville, Florida 32611 ${ }^{1}$; Gulf Coast Research \\ and Education Center, Bradenton, Florida 342032; and Department of Plant Pathology, \\ University of Hawaii, Honolulu, Hawaii $96822^{3}$
}

\begin{abstract}
Two genetically diverse groups of strains were identified among cultures of Xanthomonas campestris pv. vesicatoria isolated from plants with bacterial spot of pepper and tomato. Group A strains do not pit pectate gels or hydrolyze starch, whereas group B strains are strongly positive for these reactions. Group A strains cause a hypersensitive reaction in plants of tomato breeding line Hawaii 7998, but group B strains do not. Other differences between the two groups of strains were discovered in tests for utilization of carbon compounds, serology, fatty acid profiles, silver-stained protein bands on sodium dodecyl sulfate-polyacrylamide gel electrophoresis gels, and DNA restriction enzyme digestion profiles. The levels of DNA homology between strains belonging to the same group were more than $74 \%$, but the levels of DNA homology between strains belonging to different groups were less than $46 \%$. The two groups of strains have different genetic backgrounds, but cause essentially the same disease of tomato and pepper.
\end{abstract}

The bacterial spot disease of tomato and pepper is caused by the bacterium Xanthomonas campestris pv. vesicatoria. Necrotic spots on leaves, stems, peduncles, and fruits are distinctive symptoms of the disease $(5,17)$. Lesions may enlarge or coalesce and cause leaves to become chlorotic and eventually die. When prevalent, lesions on fruits result in loss of marketability. Bacterial spot occurs in all regions of the world where tomatoes and peppers are grown (17).

A large collection of strains of the bacterial spot pathogen of tomato and pepper was accumulated for study (4), and two characteristics, pitting of pectate gels and hydrolysis of starch, were determined for each strain as aids for identifying possible opportunistic xanthomonads in the collection (14). Strains that were pectolytic and amylolytic, characteristics expected for opportunistic xanthomonads, were discovered, but these strains were pathogenic for tomato and/or pepper. One of the pectolytic and amylolytic strains was from Brazil and was designated a new race of $X$. campestris pv. vesicatoria on the basis of its ability to cause disease in the resistant tomato breeding line Hawaii 7998 (29). Of 522 strains tested (4), 104 were pectolytic and amylolytic. Most of these 104 strains were from Argentina, but similar strains were received from Australia, Brazil, New Zealand, and Spain. Only 1 of 331 strains from the United States was pectolytic and amylolytic, and no such strain was among the 28 strains from Taiwan tested. The pectolytic and amylolytic strains were not evenly distributed in all regions of the world where bacterial spot of tomato and pepper occurs, but seemed to be most prevalent in countries in the southern hemisphere.

The two groups of strains, which are placed in $X$. campestris pv. vesicatoria because of their host specificity, were further characterized to determine the extent of genotypic

\footnotetext{
* Corresponding author. Mailing address: Plant Pathology Department, University of Florida, 1453 Fifield Hall, P.O. Box 110680, Gainesville, FL 32611-0680. Phone: (904) 392-7244. Fax: (904) 392-6532. Electronic mail address: REST@GNV.IFAS.UFL.EDU. $\dagger$ Florida Agricultural Experiment Station Journal Series no. R-03262.
}

and phenotypic diversity of these organisms. Several criteria were used for characterization, including carbon utilization patterns, serology data, fatty acid profiles, protein profiles as determined by sodium dodecylsulfate (SDS)-polyacrylamide gel electrophoresis (PAGE), DNA restriction enzyme digestion data, and DNA homology data. The purpose of this work was to determine the extent of genetic variation among strains assigned to a pathovar of $X$. campestris and to provide a better understanding of the pathogen of bacterial spot of tomato and pepper.

\section{MATERIALS AND METHODS}

Bacterial strains and inoculum preparation. Ten nonpectolytic and nonamylolytic (group A) and 10 pectolytic and amylolytic (group B) strains originally isolated from tomatoes and peppers were selected for characterization. The origins of the strains are shown in Table 1. Many of the strains had been stored as suspensions in screw-cap tubes containing sterile tap water. All were preserved in $15 \%$ glycerol at $-70^{\circ} \mathrm{C}$ for long-term storage during this work.

Pathogenicity tests. Single colonies were transferred to nutrient broth and shaken overnight at $30^{\circ} \mathrm{C}$, and the bacterial suspensions were centrifuged. The resulting pellets were resuspended in sterile tap water, and the suspensions of cells were standardized to an optical density at $600 \mathrm{~nm}$ of 0.3 (concentration equal to $5 \times 10^{8} \mathrm{CFU} / \mathrm{ml}$ ). Seedlings of tomato (cultivar Bonny Best and breeding line Hawaii 7998) and pepper (cultivar Early Calwonder) were transferred to $10-\mathrm{cm}$ pots containing a steamed peat-vermiculite mixture in a greenhouse $\left(23\right.$ to $\left.35^{\circ} \mathrm{C}\right)$. A soluble $20-20-20$ fertilizer $(0.4 \mathrm{~g}$ per pot; Peters Fertilizer Products, W. R. Grace \& Co., Fogelsville, $\mathrm{Pa}$.) was added to the plants biweekly. After 4 weeks the plants were transplanted to $15-\mathrm{cm}$ pots. To observe the disease symptoms produced by the different strains, leaves of both tomato (cultivar Bonny Best) and pepper plants were inoculated by swabbing inoculum onto leaves that were not fully expanded with a cotton applicator saturated with a bacterial suspension amended with carborundum. After inoculation, symptom development was observed periodically for 3 weeks. Fully expanded leaflets of 
TABLE 1. Strains of $X$. campestris pv. vesicatoria and $X$. campestris pv. campestris used in this study

\begin{tabular}{|c|c|c|c|}
\hline Strain & $\begin{array}{l}\text { Location of } \\
\text { isolation }\end{array}$ & $\begin{array}{l}\text { Isolated } \\
\text { from: }\end{array}$ & Source $^{a}$ \\
\hline \multicolumn{4}{|l|}{ P. campestris pv. vesicatoria } \\
\hline \multicolumn{4}{|l|}{ Group A strains ${ }^{b}$} \\
\hline $75-3$ & Florida & Tomato & Stall \\
\hline $87-21$ & Brazil & Tomato & Poulos \\
\hline $87-47$ & Taiwan & Tomato & Wang \\
\hline $87-44$ & Taiwan & Pepper & Wang \\
\hline $86-46$ & Florida & Pepper & Stall \\
\hline $86-2$ & Florida & Tomato & Stall \\
\hline $82-4$ & Florida & Pepper & Stall \\
\hline $85-16$ & Florida & Tomato & Stall \\
\hline $86-22$ & Florida & Pepper & Stall \\
\hline $89-10$ & Australia & Pepper & Hibberd \\
\hline \multicolumn{4}{|l|}{ Group B strains $^{b}$} \\
\hline 56 & Brazil & Tomato & Nagai \\
\hline 0226 & Australia & Tomato & Hibberd \\
\hline 0350 & Australia & Tomato & Hibberd \\
\hline $71-4$ & New Zealand & Tomato & Starr \\
\hline BA $27-1$ & Argentina & Pepper & Alippi \\
\hline BA 29-1 & Argentina & Tomato & Alippi \\
\hline BV 20-3A & Argentina & Tomato & Canteros \\
\hline BV 5-3A & Argentina & Tomato & Canteros \\
\hline BV 5-4A & Argentina & Tomato & Canteros \\
\hline BV 5-4B & Argentina & Tomato & Canteros \\
\hline $\begin{array}{l}X . \text { campestris pv. campestris } \\
\text { ATCC } 33913^{\text {Tc }}\end{array}$ & & & ATCC \\
\hline
\end{tabular}

a Alippi, A. Alippi, Universidad Nacional de la Plata, La Plata, Buenos Aires, Argentina; ATCC, American Type Culture Collection, Rockville, Md.; Canteros, B. Canteros, INTA, Bella Vista, Corrientes, Argentina; Hibberd, A. M. Hibberd, Redlands Horticultural Research Center, Cleveland, Queensland, Australia; Nagai, H. Nagai, Instituto Agronomico, Campinas, Brazil; Poulos, $\bullet$. Poulos, EMBRAPA, Brasilia, Brazil; Stall, R. E. Stall, this study; Starr, M. P. Starr, University of California at Davis, Davis; Wang, J.-F. Wang, AVRDC, Shanhua, Tainan, Taiwan.

${ }^{b}$ Group A strains are nonpectolytic and nonamylolytic; group B strains are pectolytic and amylolytic.

${ }^{c} \mathrm{~T}=$ type strain.

cultivar Bonny Best and Hawaii 7998 plants were infiltrated with unamended inoculum to test for hypersensitivity. The plants were then transferred to a growth chamber kept at $24^{\circ} \mathrm{C}$. Ratings for necrosis were recorded daily for 5 days.

Pectate utilization and starch hydrolysis. A depression in the medium around a bacterial colony on CVP medium (6) prepared without crystal violet or on Hildebrand's B medium (15) was scored as a positive reaction for pectolytic activity. Starch hydrolysis was determined on nutrient agar supplemented with $1.5 \%$ soluble starch. A positive reaction consisted of copious growth and a turbid halo around each colony. These reactions were associated with starch hydrolysis previously by flooding the plates with Lugol's iodine solution. Pectolytic and amylolytic activities were scored 48 $\mathrm{h}$ after transfer of bacteria to the media.

Carbon source utilization. The 20 strains were tested for utilization of 95 carbon sources with GN MicroPlates (Biolog, Inc., Hayward, Calif.). Single colonies were transferred from nutrient agar to Trypticase soy broth agar for 24 $\mathrm{h}$ of growth at $27^{\circ} \mathrm{C}$. The bacteria were removed from Trypticase soy broth agar with a sterile cotton swab and suspended in sterile saline, and each suspension was adjusted to an optical density at $590 \mathrm{~nm}$ of 0.19 . Then, $150 \mu \mathrm{l}$ of the adjusted suspension was added to each well of a GN MicroPlate. After incubation for $24 \mathrm{~h}$ at $28^{\circ} \mathrm{C}$, the $A_{550}$ of each well was determined with a plate reader (model EAR 400; SLT Lab Instruments USA, Inc., Ronkonkoma, N.Y.).
A data base of the reaction patterns was used to create a dendrogram with the software program accompanying the Biolog system.

Serology. (i) MAb production. Monoclonal antibodies (MAbs) were produced separately in Hawaii and in Florida. In Hawaii, the antibodies were produced as described previously by using formalin-killed whole-cell preparations of strains as immunizing antigens (1). In Florida, BALB/c mice were immunized twice, 12 days apart, by intraperitoneal injection of $10^{8}$ whole cells mixed $1: 1$ with Ribi's adjuvant (Ribi Immno-Chem Research, Inc., Hamilton, Mont.). Each mouse was hyperimmunized 3 days before its spleen was removed. The splenocytes were mixed 7:1 with washed $\mathrm{Sp} 2 / 0$ myeloma cells, centrifuged, and resuspended in $50 \%$ polyethylene glycol for $1 \mathrm{~min}$ to accomplish fusion. Over the next $5 \mathrm{~min}, 1 \mathrm{ml}$ of HAT (hypoxanthine, aminopterin, and thymidine) medium was added every $10 \mathrm{~s}$. The mixture was centrifuged, resuspended in HAT medium, and dispensed into 96-well culture plates. The supernatants were screened after 12 days with the homologous antigen (strain 75-3) and a heterologous antigen (strain 56) by performing an enzymelinked immunosorbent assay (ELISA). Hybridomas producing antibodies that reacted differently with the two strains and hybridomas producing antibodies that reacted equally well with the two strains were selected. These hybridomas were then cloned by limiting dilution.

(ii) ELISA procedure. The antigens consisted of whole cells suspended in $0.01 \mathrm{M}$ carbonate buffer $(\mathrm{pH}$ 9.6) and adjusted to an optical density at $600 \mathrm{~nm}$ of 0.6 . They were spread onto Immulon 2 microtiter plates (Dynatech Laboratories, Inc., Chantilly, Va.) and incubated overnight in a moist environment at $4^{\circ} \mathrm{C}$. The plates were washed with phosphate-buffered saline-Tween, and then $1 \%$ bovine serum albumin (Sigma Chemical Co., St. Louis, Mo.) was added to the wells. Appropriate dilutions of MAbs were added directly to the wells, and the preparations were incubated for $1 \mathrm{~h}$ at $37^{\circ} \mathrm{C}$. The wells were washed again before alkaline phosphatase conjugated to anti-mouse immunoglobulin $G$ was added, and the preparations were incubated as described above for MAbs. The plates were then washed, and $100 \mu \mathrm{l}$ of an enzyme substrate buffer containing $p$-nitrophenyl phosphate (Sigma) was added to each well (28). The enzyme activity for substrate conversion was quantified for each well by measuring $A_{405}$ with a model EAR 400 plate reader. An $A_{405}$ of 0.12 after $60 \mathrm{~min}$ of incubation was considered a positive reaction.

Fatty acid analyses. The fatty acid profiles of $\mathbf{3 9}$ group A strains and 39 group B strains were analyzed. The 20 strains listed in Table 1 were included among the strains examined. A single colony of each strain was transferred from a nutrient agar culture to Trypticase soy broth agar, and after $24 \mathrm{~h}$ of growth at $28^{\circ} \mathrm{C}$ approximately $40 \mathrm{mg}$ of cells was collected for analysis. The bacterial fatty acids were derivatized to their methyl esters (20), separated by gas chromatography (23), and identified by using the Microbial Identification System software (version 3.6; MIDI, Newark, Del.). The relationships of the strains based on fatty acid analysis data were determined by analyzing principal components with MIDI software.

Electrophoresis of soluble proteins. The strains listed in Table 1 were characterized by one-dimensional electrophoretic separation of whole-cell proteins, using the method of Laemmli (18) as modified by Jackman (16). Single colonies were transferred to nutrient broth and incubated with shaking for $16 \mathrm{~h}$ at $28^{\circ} \mathrm{C}$. The cells were harvested by centrifugation and washed twice in sterile deionized water, and then 
approximately $20 \mathrm{mg}$ was suspended in $180 \mu \mathrm{ll}$ of $10 \%$ sorbitol. Each cell suspension was mixed with an equal volume of double-strength lysis buffer $(125 \mathrm{mM}$ Tris- $\mathrm{HCl}$ [pH 6.8], 4\% SDS, 10\% 2-mercaptoethanol, $20 \%$ glycerol) containing $0.01 \%$ bromophenol blue. The suspension was heated at $100^{\circ} \mathrm{C}$ for $10 \mathrm{~min}$ and centrifuged at $16,000 \times g$ for 10 min to pellet the cellular debris. The supernatant containing water-soluble proteins was then removed carefully and stored at $-20^{\circ} \mathrm{C}$ until it was needed. Before the protein solution was loaded, the sample was thawed at room temperature and heated at $50^{\circ} \mathrm{C}$ for $10 \mathrm{~min}$. The proteins were separated with a discontinuous gel consisting of a stacking gel (5\% total acrylamide with $2.7 \%$ cross-linking $N, N^{\prime}$ bismethyleneacrylamide, $125 \mathrm{mM}$ Tris- $\mathrm{HCl}$ [pH 6.8], $0.1 \%$ SDS) layered on top of a separation gel (10\% total acrylamide with $2.7 \%$ cross-linking $N, N^{\prime}$-bismethyleneacrylamide, $375 \mathrm{mM}$ Tris- $\mathrm{HCl}$ [pH 8.8], 0.1\% SDS). Electrophoresis was performed at $4^{\circ} \mathrm{C}$ by using a Protean II double-slab vertical electrophoresis cell (Bio-Rad Laboratories, Richmond, Calif.) filled with electrophoresis buffer $(250 \mathrm{mM}$ Tris [pH 8.3 ], $192 \mathrm{mM}$ glycine, $0.1 \%$ SDS). A constant current of 25 $\mathrm{mA}$ per gel was applied until the bromophenol blue reached the separation gel (ca. $45 \mathrm{~min}$ ). The current was then increased to $35 \mathrm{~mA}$ per gel until the tracking dye had migrated about $100 \mathrm{~mm}$ through the separation gel (ca. $3 \mathrm{~h}$ ). The gel was stained for proteins at room temperature with a silver staining kit (Sigma) and finally dried between two sheets of cellophane.

Restriction endonuclease analysis. Genomic DNAs of the 20 group A and B strains listed in Table 1 were prepared and digested with restriction enzymes $X b a I$ and SpeI as described previously (9). The large DNA fragments were separated by pulsed-field electrophoresis. The gels were stained with $0.5 \mathrm{mg}$ of ethidium bromide per liter and photographed with type 55 Polaroid film. The fragments of all 20 strains were compared on the same gel, and similarity coefficients were determined for strains that shared fragments larger than $100 \mathrm{~kb}(9)$. The KITSCH program from the PHYLIP computer package (10) was used to infer a rooted phylogenetic tree by using the Fitch-Margoliash method (11). The input data consisted of a matrix of pairwise genetic distances determined as estimates of the numbers of nucleotide substitutions per site on the basis of similarity coefficients calculated for the combined SpeI and $\mathrm{XbaI}$ digestion data.

DNA-DNA hybridization. The experimental procedure used for DNA reassociation experiments has been described previously (9). The DNA of one strain belonging to each group (strains 75-3 and 56) was labeled by incorporating tritiated dCTP into sheared genomic DNA by the random primer method. Each labeled DNA was hybridized with sheared DNAs of the 20 group A and B strains listed in Table 1. Labeled double-stranded DNA was incorporated onto Whatman GF/C glass fiber filters, and radioactivity was quantified by liquid scintillation counting. The hybridization values for pairs of strains were means of the values from two experiments; in each experiment two hybridization reactions were performed.

\section{RESULTS}

Pathogenicity tests. The strains of the two groups caused slightly different symptoms in tomato and pepper leaves. Lesions that were raised above the leaf surface developed when group A strains were inoculated onto tomato and pepper leaves by the swabbing technique. A whitish halo

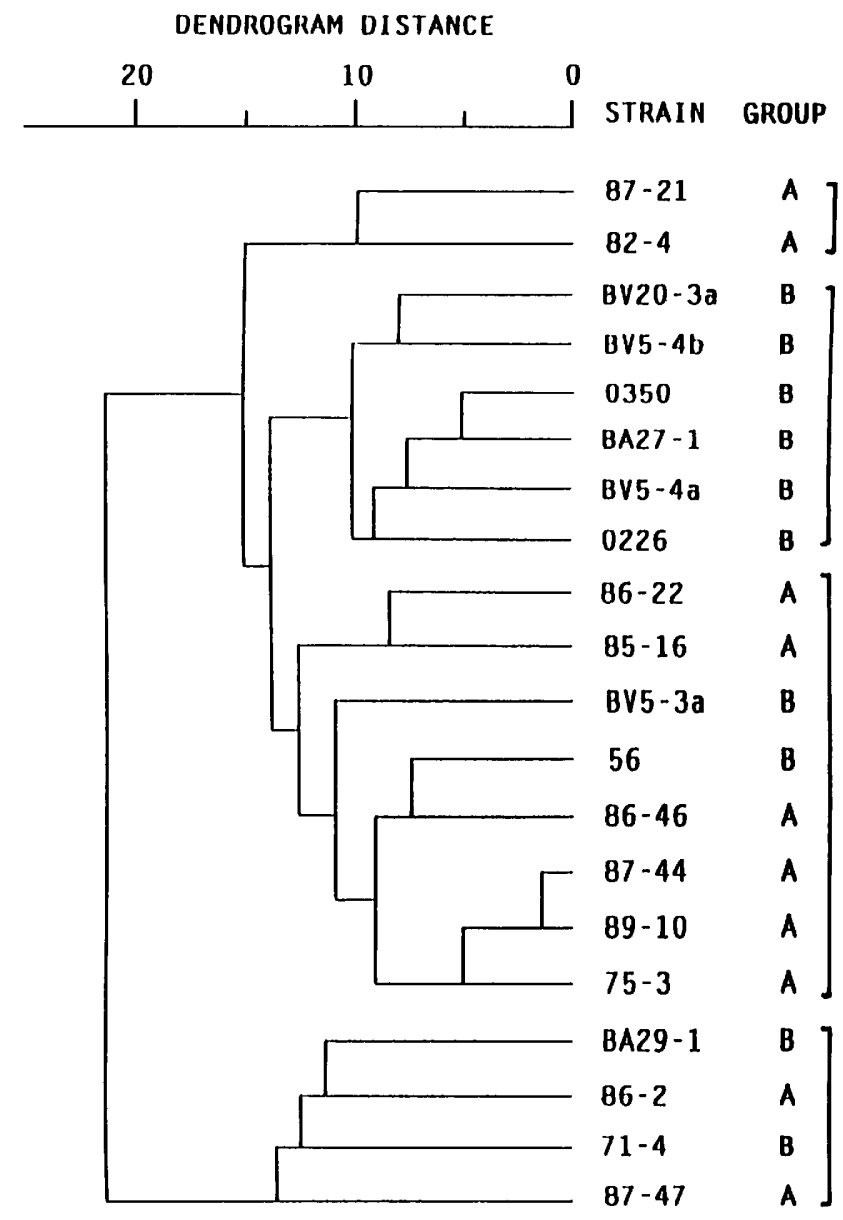

FIG. 1. Dendrogram of relationships based on patterns of carbon substrate utilization by $X$. campestris pv. vesicatoria strains.

surrounded each lesion as it appeared. In contrast, the group B strains caused lesions that were sunken or level with the leaf surface and were not surrounded by whitish halos. The differences were obvious only when lesions first formed after inoculation. Differences in the frequency or diameter of lesions caused by strains of the two groups were not detected. Both types of strains caused chlorosis and epinasty of tomato and pepper leaves.

Necrosis occurred in leaves of tomato line Hawaii 7998 within $24 \mathrm{~h}$ after infiltration with high populations of all group A strains. Necrosis occurred after $72 \mathrm{~h}$ in the same type of leaves infiltrated with all group B strains. Necrosis in leaves of cultivar Bonny Best plants occurred after $72 \mathrm{~h}$ with strains of both groups.

Pectate utilization and starch hydrolysis. The group A strains selected for this research were consistently nonamylolytic and nonpectolytic. The group B strains were amylolytic and pectolytic.

Carbon source utilization. A cluster analysis of the patterns of utilization of 95 carbon sources revealed relative diversity among the 20 strains examined. Four clusters of strains were differentiated at a dendrogram distance of 12 (Fig. 1). One cluster consisted of two group A strains; another cluster contained six group B strains; a third cluster contained six group A strains and two group B strains; and a fourth cluster contained two group A strains and two group 
TABLE 2. Serological reactions of MAbs with strains of $X$. campestris pv. vesicatoria

\begin{tabular}{|c|c|c|c|c|}
\hline \multirow{2}{*}{ Strain } & \multicolumn{4}{|c|}{ Reaction with: } \\
\hline & MAb 5D12 & MAb 3 & MAb 4H5 & MAb 15 \\
\hline \multicolumn{5}{|c|}{ Group A strains $^{a}$} \\
\hline $75-3$ & $t^{b}$ & + & - & - \\
\hline $82-4$ & + & + & - & - \\
\hline $85-16$ & + & - & - & - \\
\hline $86-2$ & + & + & - & - \\
\hline $87-21$ & + & + & - & - \\
\hline $89-10$ & + & + & - & - \\
\hline $86-46$ & + & + & - & - \\
\hline $87-47$ & + & + & - & - \\
\hline $86-22$ & - & + & - & - \\
\hline $87-44$ & - & + & - & - \\
\hline \multicolumn{5}{|c|}{ Group B strains $^{a}$} \\
\hline $56^{\circ}$ & + & - & + & - \\
\hline 0226 & + & - & + & - \\
\hline 0350 & + & - & + & - \\
\hline BV 5-3A & + & - & + & - \\
\hline BV 5-4B & + & - & + & - \\
\hline BV 20-3A & + & - & + & - \\
\hline BA $27-1$ & - & - & - & + \\
\hline BA 29-1 & - & - & - & + \\
\hline BV 5-4A & - & - & - & + \\
\hline $71-4$ & - & - & - & - \\
\hline
\end{tabular}

${ }^{a}$ Group A strains are nonpectolytic and nonamylolytic; group B strains are pectolytic and amylolytic.

${ }^{b}+$, positive $\left(A_{405}\right.$ of 0.12 or greater in the ELISA); - , negative. The $A_{405}$ value of 0.12 is an arbitrary threshold which is three times the $A_{405}$ of heterologous strains.

B strains. Specifically, 9 of the 10 group A strains but none of the group B strains utilized cis-aconitic acid. D-Mannitol, succinamic acid, alpha-hydroxybutyric acid, and L-aspartic acid also helped distinguish the two groups of strains. Seven, eight, six, and six of the group B strains and $0,2,1$, and 1 of the group A strains, respectively, used these compounds.

Serology. Three MAbs could be used to differentiate most of the strains in the two groups (Table 2). MAb 3 reacted with all but one of the group A strains and none of the group $B$ strains. Either MAb $4 \mathrm{H} 5$ or MAb 15 reacted with all but one of the group B strains, but neither of these MAbs reacted with any of the group A strains. MAb 5D12 reacted with most strains of both groups.

Fatty acid profiles. The fatty acid profiles of all strains were qualitatively similar and were typical $X$. campestris profiles $(22,25)$. However, several quantitative differences statistically separated the two groups of strains. The ratio of the 15:0 iso acid to 15:0 anteiso acid for group A strains was near 3:1, compared with a ratio of $2: 1$ for the group B strains. The two groups of strains formed two clusters with some overlap in a principal component analysis (Fig. 2). A dendrogram (data not shown) of the relationships of the strains produced some clusters that contained both types of strains, apparently because of the overlap of strains in the two groups.

Electrophoresis of soluble proteins. A large number of discrete bands at molecular weights ranging from about 14,000 to more than 100,000 were present in the protein extracts of the strains (Fig. 3). The group A and B strains were clearly different in the low-molecular-weight region. Specifically, the group A strains shared a ca. $32-\mathrm{kDa}$ protein band, whereas the group B strains shared another protein with a lower molecular weight (about 27,000). Of a total of 67

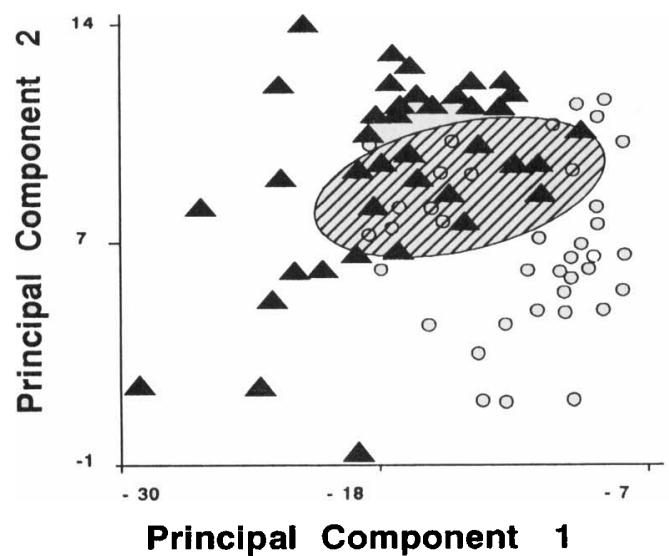

FIG. 2. Principal component analysis of the fatty acid profiles of 38 group A strains $(\mathbf{A})$ and 38 group B strains $(O)$. The cross-hatched area represents strain profile.

group B strains tested (1a), 3 expressed the $27-\mathrm{kDa}$ band only occasionally. This group of strains is represented by strain BA 29-1 in Fig. 3.

Restriction endonuclease analysis. After digestion of genomic DNAs with $X b a I$, the similarity coefficients ranged from 0.71 to 1.00 in comparisons of the 10 group A strains with each other. The similarity coefficients for the 10 group B strains ranged from 0.29 to 1.00 . In comparisons of groups $\mathrm{A}$ and $\mathrm{B}$ the similarity coefficients ranged from 0.00 to 0.38 . Digestion with SpeI resulted in similarity coefficients ranging from 0.50 to 0.96 for the group A strains and 0.31 to 1.00 for the group B strains. The similarity coefficients for groups A

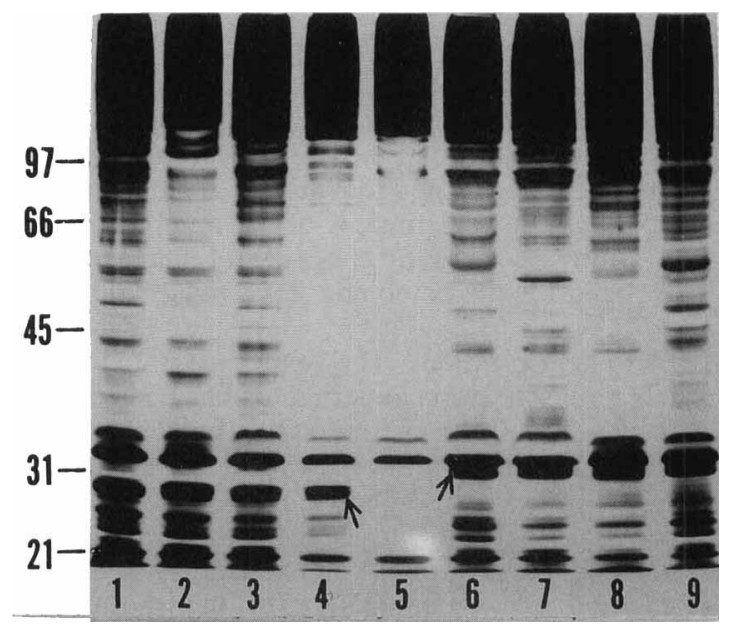

FIG. 3. Electropherogram of denatured proteins from SDS-lysed cells of $X$. campestris pv. vesicatoria. Lanes 1 through 5, lysates from group B strains 56, 0226, BA 27-1, 71-4, and BA 29-1, respectively; lanes 6 through 9, lysates from group A strains 75-3, $86-46,89-10$, and $87-44$, respectively. The following protein molecular weight markers were used (from top to bottom): rabbit phosphorylase B (molecular weight, 97,000), bovine serum albumin $(66,000)$, hen egg white ovalbumin $(45,000)$, bovine carbonic anhydrase $(31,000)$, and soybean trypsin inhibitor $(21,000)$. Silver staining revealed a $32-\mathrm{kDa}$ band (arrow) in the nonamylolytic and nonpectolytic strain lysates (lanes 6 through 9) and a $27-\mathrm{kDa}$ band (arrow) in the amylolytic and pectolytic strain lysates (lanes 1 through 4). In one amylolytic and pectolytic strain (lane 5) the $27-\mathrm{kDa}$ band was not present. 


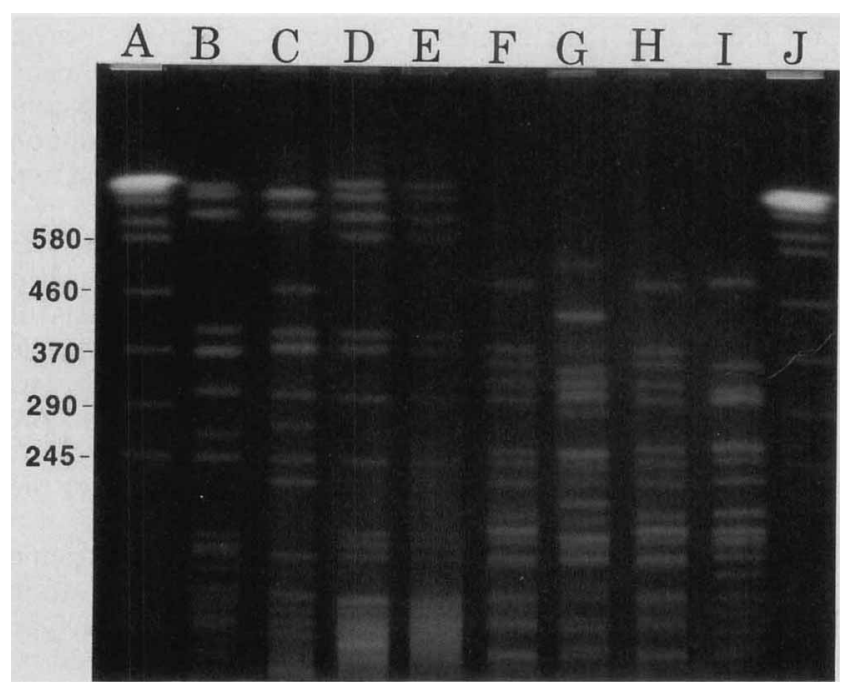

FIG. 4. Bands of DNAs from $X$. campestris pv. vesicatoria strains separated by pulsed-field electrophoresis after genomic DNAs were digested with restriction enzyme SpeI. Lanes A and J contained yeast chromosomal DNA as markers, and the sizes (in kilobases) of some of the bands are indicated on the left. Lanes B through E contained DNAs from group A strains 75-3, 86-2, 89-10, and 87-21, respectively, and lanes $F$ through I contained DNAs from group B strains 56, BV 5-4A, BV 20-3A, and 0350, respectively. The group B strains (lanes 6 through 9) did not produce bands larger than $600 \mathrm{~kb}$.

and B were 0.08 to 0.26 . The group A strains consistently produced bands near 600 to $800 \mathrm{~kb}$, but no bands above 600 kb were present with group B strains (Fig. 4). The two groups of strains formed separate clusters in a tree constructed by using data for pairwise genetic distances. Greater genetic divergence occurred within the group B strains than within the group A strains (Fig. 5).

DNA-DNA hybridization. The levels of hybridization between DNAs of the group A strains and DNA of strain 75-3 (group A) ranged from 79 to $119 \%$, whereas the levels of hybridization between DNAs of group B strains and DNA of strain 75-3 ranged from 0 to $42 \%$ (Table 3). The levels of hybridization between DNAs of group A strains and DNA of strain 56 (group B) ranged from 14 to $46 \%$, whereas the levels of hybridization between DNAs of group B strains and DNA of strain 56 ranged from 74 to $108 \%$. The average hybridization values within groups A and B were 98.2 and $90.8 \%$, respectively. The average level of hybridization between DNAs from group A strains and a group B strain was $33 \%$, and the average level of hybridization between DNAs from group B strains and a group A strain was $17 \%$. The levels of DNA homology of strains 75-3 and 56 to the type strain of $X$. campestris were 42 and $32 \%$, respectively.

\section{DISCUSSION}

Many discriminating techniques were used to determine the phenetic and genetic characteristics of the two groups of Xanthomonas strains isolated from bacterial spot of tomato and pepper, as suggested by Vauterin et al. (26) for work with the genus Xanthomonas. Collectively, our results support the conclusion that there are significant genetic differences between the two groups. The differences in pathogenicity between the two groups were consistent, but these differences may be the result of differences in only a few

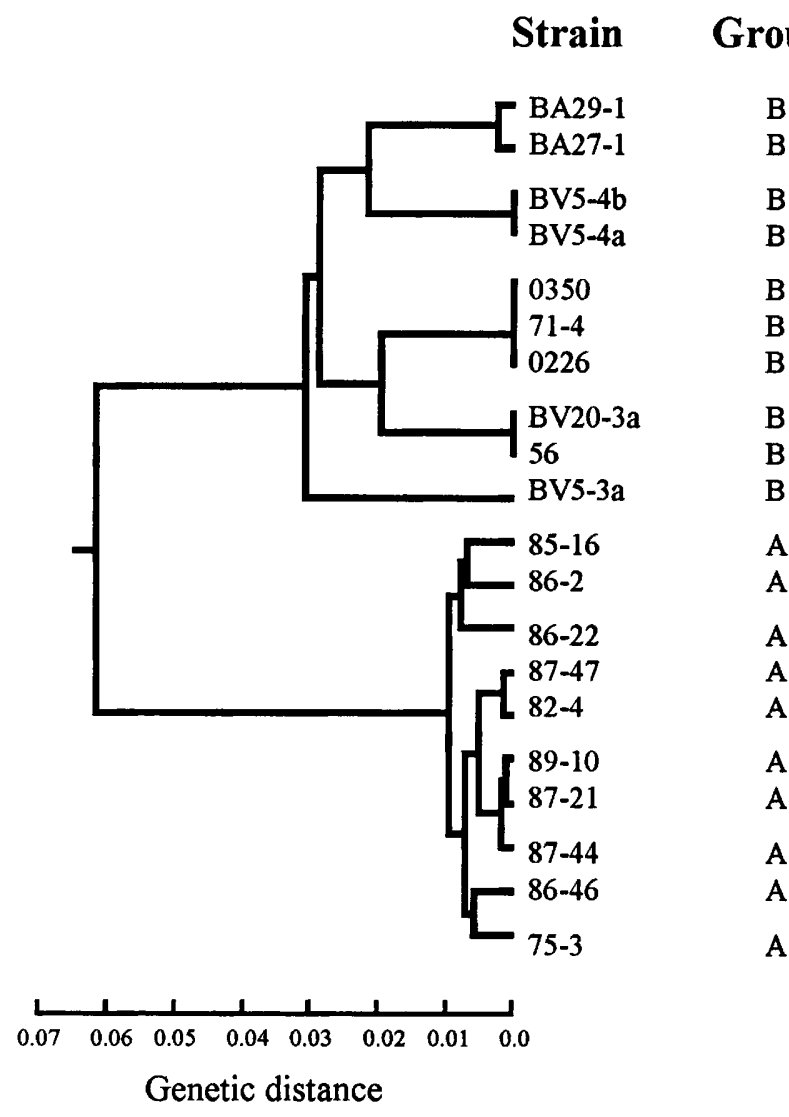

FIG. 5. Clustering of group A and B strains inferred from similarity coefficients obtained from SpeI and $X b a I$ restriction endonuclease digestion data. The tree was generated by the KITSCH procedure with the PHYLIP computer package by using the FitchMargoliash method. The genetic distances are estimates of the numbers of nucleotide substitutions per site.

genes. Likewise, the genetic basis associated with the differences detected in carbon utilization patterns could have been small. The two groups of strains could be differentiated with a series of MAbs, but some antigens were present in both groups. Fatty acid analysis data differentiated two clusters of strains, but portions of the clusters overlapped. Differences in the profiles of silver-stained proteins were detected, and the DNA fingerprints of restriction enzyme sites helped assess the extent of the differences between the two groups of strains. DNA-DNA hybridization values for the two groups of strains gave the best portrait of the extent of the genetic differences between the groups of strains.

Groups A and B may correspond to subgroups A and B of $X$. campestris $\mathrm{pv}$. vesicatoria designated previously by Vauterin et al. (25). In the study of Vauterin et al. a numerical analysis of SDS-PAGE proteins stained with Coomassie blue was completed with 17 strains. Two major clusters were distinguished. Subgroup A was in DNA homology group 1 (26), but subgroup B was not placed in a DNA homology group. Subgroup B contained the pathovar reference strain.

Starch hydrolysis helps distinguish the two groups of strains that can be isolated from lesions on plants with bacterial spot of tomato and pepper. Burkholder and $\mathrm{Li} \mathrm{(2)}$ pointed out many years ago that strains of the bacterial spot pathogen differed in hydrolysis of starch. Strains obtained from tomato were strongly diastatic, and strains obtained 
TABLE 3. Levels of homology between DNAs from

$X$. campestris pv. vesicatoria group $\mathrm{A}$ and $\mathrm{B}$ strains and the type strain of $X$. campestris and DNA from a representative of each group

\begin{tabular}{|c|c|c|}
\hline \multirow[b]{2}{*}{ Strain } & \multicolumn{2}{|c|}{ \% Hybridization with: } \\
\hline & $\begin{array}{c}\text { Strain } 75-3 \\
\text { DNA }\end{array}$ & $\begin{array}{c}\text { Strain } 56 \\
\text { DNA }\end{array}$ \\
\hline \multicolumn{3}{|l|}{$X$. campestris pv. vesicatoria } \\
\hline $75-3$ & 100 & 14 \\
\hline $87-21$ & 79 & 39 \\
\hline $87-47$ & 101 & 46 \\
\hline $87-44$ & 82 & 35 \\
\hline $86-46$ & 114 & 15 \\
\hline $86-2$ & 85 & 31 \\
\hline $82-4$ & 99 & 40 \\
\hline $85-16$ & 115 & 29 \\
\hline $86-22$ & 119 & 34 \\
\hline $89-10$ & 91 & 31 \\
\hline \multicolumn{3}{|l|}{ Group B strains $^{a}$} \\
\hline $56^{\circ}$ & 25 & 100 \\
\hline 0226 & 6 & 104 \\
\hline 0350 & 13 & 77 \\
\hline $71-4$ & 0 & 108 \\
\hline BA $27-1$ & 42 & 84 \\
\hline BA 29-1 & 14 & 74 \\
\hline BV 20-3A & 38 & 88 \\
\hline BV 5-3A & 7 & 88 \\
\hline BV 5-4A & 14 & 95 \\
\hline BV 5-4B & 15 & 99 \\
\hline $\begin{array}{l}X . \text { campestris pv. campestris } \\
\text { ATCC } 33913^{\mathrm{T}}\end{array}$ & 42 & 32 \\
\hline
\end{tabular}

${ }^{a}$ Group A strains are nonpectolytic and nonamylolytic; group B strains are pectolytic and amylolytic.

from pepper were not. These workers may have been dealing with the two groups described here. Schaad also reported that two serotypes of $X$. campestris pv. vesicatoria differed in hydrolysis of starch (24). Cultures from the collections used in these two studies will have to be tested with other techniques to determine whether Burkholder and $\mathrm{Li} \mathrm{(2)}$ and Schaad (24) were dealing with the two groups of strains described here.

Members of both groups are pathogenic for tomato and/or pepper. The host ranges of the groups of strains are not considered to be important because host range is determined by avirulence genes carried on plasmids $(3,21)$. The majority of the group B strains contain the avirulence gene avrBsT, which results in incompatibility in all Capsicum species (21). Some group A strains also contain avrBsT, and other group A strains contain another avirulence gene, $a v r B s P$, which results in incompatibility in Lycopersicon species (3). In addition, there may be some solanaceous hosts other than tomato and pepper for one or both groups, but this has not been determined. Other solanaceous hosts of $X$. campestris pv. vesicatoria have been described previously (19), and some of them occur only in local geographic regions.

Dye et al. (8) designated a neopathotype for $X$. campestris pv. vesicatoria in 1980. Jones and Bouzar (17a) determined that this strain belongs to our group B. This strain may not represent the original description of the bacterium by Doidge (7), because the bacterium causing bacterial spot of tomato in South Africa only weakly hydrolyzed starch after 14 days. Gardner and Kendrick (12), unaware of Doidge's description, also described the pathogen of bacterial spot of tomato and found that their strains hydrolyzed starch in 2 days. They named their bacterium Bacterium exitiosum, a name which was withdrawn because the two bacteria were considered to be the same pathogen and Doidge's description had priority (13). On the basis of starch hydrolysis, the two bacteria represent the two groups described here.

Genetic diversity of strains within pathovars of $X$. campestris is not unusual. Three groups were distinguished among strains of $X$. campestris pv. citri on the basis of pathogenicity (9). Strains of the three groups exhibited levels of DNA homology of more than $60 \%(9,27)$, which was interpreted to mean that all of the strains belonged to the same species (27). Strains that exhibited levels of DNA homology greater than $85 \%$, however, corresponded to the three groups.

The nomenclature of the two groups of strains pathogenic for tomato and pepper is a problem. DNA from a strain belonging to each group hybridized to DNA from the type culture of $X$. campestris at a level $(<50 \%)$ which could be used to justify new species (30). However, determination of levels of DNA homology with representatives of DNA hybridization groups, some of which are listed by Vauterin et al. (26), should be completed before the two groups of strains are classified. The use of two species names for strains that essentially cause the same disease in tomato and pepper may be confusing to researchers working in agriculture. Clearly, the two groups must be distinguished in tomato breeding programs, because tomato resistance differs for the two groups. At present, the two groups of strains are known as race 1 and race 2 of the tomato group of strains (28). However, designation of races is not adequate to distinguish the groups, because race implies differences in strains only at the pathogenicity level. We suggest that these groups should be designated groups $\mathrm{A}$ and $\mathrm{B}$ of $X$. campestris pv. vesicatoria, until the correct taxonomic position of the two groups of strains within the genus Xanthomonas has been determined.

\section{REFERENCES}

1. Alvarez, A. M., A. A. Benedict, and C. Y. Mizumoto. 1985. Identification of xanthomonads and grouping of strains of Xanthomonas campestris pv. campestris with monoclonal antibodies. Phytopathology 75:722-728.

1a.Bouzar, H. Unpublished data.

2. Burkholder, W. H., and C. C. Li. 1941. Variations in Phytomonas vesicatoria. Phytopathology 31:753-755.

3. Canteros, B., G. Minsavage, U. Bonas, D. Pring, and R. Stall. 1991. A gene from Xanthomonas campestris pv. vesicatoria that determines avirulence in tomato is related to avrBs3. Mol. Plant Microbe Interact. 4:628-632.

4. Canteros, B. I. 1990. Diversity of plasmids and plasmid-encoded phenotypic traits in Xanthomonas campestris pv. vesicatoria. Ph.D. dissertation. University of Florida, Gainesville.

5. Cox, R. S., R. A. Conover, and G. Sowell. 1956. Symptomology of bacterial spot of pepper and tomato in southern Florida. Phytopathology 46:582-584.

6. Cuppels, D., and A. Kelman. 1974. Evaluation of selective media for isolation of soft-rot bacteria from soil and plant tissue. Phytopathology 64:468-475.

7. Doidge, E. M. 1921. A tomato canker. Ann. Appl. Biol. 7:407429.

8. Dye, D. W., J. F. Bradbury, M. Goto, A. C. Hayward, R. A Lelliott, and M. N. Schroth. 1980. International standards for naming pathovars of phytopathogenic bacteria and a list of pathovar names and pathotype strains. Rev. Plant Pathol. 59:153-168.

9. Egel, D. S., J. H. Graham, and R. E. Stall. 1991. Genomic relatedness of Xanthomonas campestris strains causing disease 
on citrus. Appl. Environ. Microbiol. 57:2724-2730.

10. Felsenstein, J. 1991. PHYLIP, phylogeny inference package, ver. 3.4. Department of Genetics, University of Washington, Seattle.

11. Fitch, W. M., and E. Margoliash. 1967. Construction of phylogenetic trees. Science 155:279-284.

12. Gardner, M. W., and J. B. Kendrick. 1921. Bacterial spot of tomato. J. Agric. Res. 21:123-156.

13. Gardner, M. W., and J. B. Kendrick. 1923. Bacterial spot of tomato and pepper. Phytopathology 13:307-315.

14. Gitaitis, R. D., M. J. Sasser, R. W. Beaver, T. B. McInes, and R. E. Stall. 1987. Pectolytic xanthomonads in mixed infections with Pseudomonas syringae pv. syringae, $P$. syringae pv. tomato, and Xanthomonas campestris pv. vesicatoria in tomato and pepper transplants. Phytopathology 77:611-615.

15. Hildebrand, D. C. 1971 . Pectate and pectin gels for differentiation of Pseudomonas sp. and other bacterial plant pathogens. Phytopathology 61:1430-1436.

16. Jackman, P. J. H. 1985. Bacterial taxonomy based on electrophoretic whole-cell patterns, p. 115-129. In M. Goodfellow and D. E. Minnikin (ed.), Chemical methods in bacterial systematics. Academic Press, London.

17. Jones, J. B. 1991. Bacterial spot, p. 27. In J. B. Jones, J. P. Jones, R. E. Stall, and T. A. Zitter (ed.), Compendium of tomato diseases. APS Press, St. Paul, Minn.

17a.Jones, J. B., and H. Bouzar. Unpublished data.

18. Laemmli, U. K. 1970. Cleavage of structural proteins during the assembly of the head of bacteriophage T4. Nature (London) 227:680-685.

19. Leyns, D., M. De Cleene, J. Swings, and J. De Ley. 1984. The host range of the genus Xanthomonas. Bot. Rev. 50:308-356.

20. Miller, L. T. 1982. Single derivatization method for routine analysis of bacterial whole-cell fatty acid methyl esters, including hydroxy acids. J. Clin. Microbiol. 16:584-586.

21. Minsavage, G. V., D. Dahlbeck, M. C. Whalen, B. Kearney, U. Bonas, B. J. Staskawicz, and R. E. Stall. 1990. Gene-for-gene relationships specifying disease resistance in Xanthomonas campestris pv. vesicatoria-pepper interactions. Mol. Plant $\mathrm{Mi}-$ crobe Interact. 3:41-53.

22. Roy, M. A. 1988 . Use of fatty acids for the identification of phytopathogenic bacteria. Plant Dis. 72:460.

23. Sasser, M. J. 1990. Identification of bacteria through fatty acid analysis, p. 199-204. In Z. Klement, K. Rudolph, and D. Sands. (ed.), Methods in phytobacteriology. Akademiai Kiado, Budapest.

24. Schaad, N. W. 1976. Immunological comparison and characterization of ribosomes of Xanthomonas vesicatoria. Phytopathology 66:770-776.

25. Vauterin, L., J. Swings, and K. Kersters. 1991. Grouping of Xanthomonas campestris pathovars by SDS-PAGE of proteins. J. Gen. Microbiol. 137:1677-1687.

26. Vauterin, L., J. Swings, K. Kersters, M. Gillis, T. W. Mew, M. N. Schroth, N. J. Palleroni, D. C. Hildebrand, D. E. Stead, E. L. Civerolo, A. C. Hayward, H. Maraite, R. E. Stall, A. K. Vidaver, and J. F. Bradbury. 1990. Towards an improved taxonomy of Xanthomonas. Int. J. Syst. Bacteriol. 40:312-316.

27. Vauterin, L., P. Yang, B. Hoste, M. Vancanneyt, E. L. Civerolo, J. Swings, and K. Kersters. 1991. Differentiation of Xanthomonas campestris pv. citri strains by sodium dodecyl sulfatepolyacrylamide gel electrophoresis of proteins, fatty acid analysis, and DNA-DNA hybridization. Int. J. Syst. Bacteriol. 41:535-542.

28. Voller, A., A. Bartlett, D. E. Bidwell, M. F. Clark, and A. N. Adams. 1976. The detection of viruses by enzyme-linked immunosorbent assay (ELISA). J. Gen. Virol. 33:165-167.

29. Wang, J.-F., J. B. Jones, J. W. Scott, and R. E. Stall. 1990. A new race of the tomato group of strains of Xanthomonas campestris pv. vesicatoria. Phytopathology 80:1070.

30. Wayne, L. G., D. J. Brenner, R. R. Colwell, P. A. D. Grimont, O. Kandler, M. I. Krichevsky, L. H. Moore, W. E. C. Moore, R. G. E. Murray, E. Stackebrandt, M. P. Starr, and H. G. Truiper. 1987. Report of the Ad Hoc Committee on Reconciliation of Approaches to Bacterial Systematics. Int. J. Syst. Bacteriol. 37:463-464. 